\title{
NILAI-NILAI AKHLAK DALAM NOVEL GURU AINI KARYA ANDREA HIRATA
}

\section{MORAL VALUES IN GURU AINI WRITTEN BY ANDREA HIRATA}

\author{
Khaerunnisa Khaerunnisa $^{1 *}$, Lutfi Syauki Faznur ${ }^{2}$, Liana Meilinda ${ }^{3}$ \\ Pendidikan Bahasa dan Sastra Indonesia, Universitas Muhammadiyah Jakarta, \\ Indonesia ${ }^{1,2,3}$ \\ $\underline{\text { khaerunnisa@umj.ac.id }}^{1}$ lutfisyauki@umj.ac.id $^{2}, \underline{\text { lianameilindaa@ gmail.com }}^{3}$ \\ *penulis korespondensi
}

\begin{tabular}{ll}
\hline Info Artikel & ABSTRAK \\
\hline Sejarah artikel: & Penelitian ini berisi tentang nilai-nilai Akhlak Al-Islam dan \\
Diterima: & Kemuhammadiyahan dalam novel Guru Aini karya Andrea Hirata. Nilai \\
20 Juli 2020 & akhlak menjadi fokus utama pada penelitian ini karena akhlak merupakan \\
Direvisi: & salah satu pondasi dasar dari sifat manusia yang sangat erat kaitannya \\
23 Desember 2020 & dengan perilaku manusia dengan Tuhannya. Penelitian ini bertujuan untuk \\
Disetujui: & memperoleh pemahaman yang mendalam mengenai nilai-nilai akhlak \\
15 Januari 2021 & berupa nilai takwa, tawakal, kejujuran, keikhlasan, sabar dan syukur dari \\
& novel Guru Aini karya Andrea Hirata. Novel tersebut memiliki nilai akhlak \\
Kata kunci: & yang perlu diterapkan dalam kehidupan bermasyarakat serta menjadi \\
Nilai-nilai akhlak, & khazanah keilmuan berkaitan antara agama dan sastra. Penelitian ini \\
karya sastra, novel & menggunakan metode kualitatif dan pendekatan analisis isi. Metode \\
& kualitatif ini dapat menghasilkan data deskriptif berupa kata-kata tertulis \\
& atau atau isi komunikasi berupa percakapan, teks tertulis, dan fotografi. \\
& Simpulan dari hasil penelitian ini terdapat 6 kutipan dari nilai takwal, 14 \\
& kutipan nilai tawakal, 18 kutipan dari nilai kejujuran, 4 kutipan dari nilai \\
& keikhlasan, 1 kutipan dari nilai sabar, dan 14 kutipan dari nilai syukur.
\end{tabular}

\begin{tabular}{ll}
\hline Article Info & ABSTRACT \\
\hline $\begin{array}{l}\text { Article history: } \\
\text { Received: }\end{array}$ & $\begin{array}{l}\text { This study contains moral values based on Al-Islam and Muhammadiyah in } \\
\text { the novel Guru Aini by Andrea Hirata. The value of akhlak (moral) is the } \\
\text { 20 July 2020 }\end{array}$ \\
$\begin{array}{l}\text { Revised: } \\
\text { 23 December 2020 }\end{array}$ & $\begin{array}{l}\text { human nature which is very closely related to human behavior with God. } \\
\text { This study aims to gain deep understanding of akhlak (moral) values in the } \\
\text { Accepted: }\end{array}$ \\
15 January 2021 & $\begin{array}{l}\text { patience and gratitude from the novel Guru Aini by Andrea Hirata. The } \\
\text { novel has a moral value that needs to be applied in social life and becomes }\end{array}$ \\
Keywords: & $\begin{array}{l}\text { a scientific treasure related to religion and literature. This research uses } \\
\text { qualitative method and content analysis approach, this qualitative method }\end{array}$ \\
literature, novel & can produce descriptive data in the form of written words or communication \\
content in the form of conversation, written text, and photography. & Conclusions from the results of this study there are 6 quotes from the value \\
of piety/morals, 14 quotes from the value of resignation / never give up, 18 \\
quotes from the value of honesty, 4 quotations from the value of sincerity, \\
1 quote from the value of patience, and 14 quotes from the value of gratitude.
\end{tabular}




\section{PENDAHULUAN}

Pada era modern ini, nilai menjadi sangat penting dalam menjaga keharmonisan dan penyelarasan pembangunan dan kemajuan. Maka nilai akhlak harus tetap dijaga dan dilestarikan kepada setiap individu tanpa terkecuali. Akhlak merupakan tingkah laku seseorang yang didorong oleh keinginan secara sadar untuk melakukan suatu perbuatan. Perbuatan tersebut seharusnya memiliki kesadaran untuk melakukan hal-hal yang baik dan sesuai ajaran Islam, sehingga tercipta suatu akhlak yang mulia.

Menurut Atjeh (2007:173) Islam adalah ajaran yang menjunjung akhlak yang mulia. Akhlak yang mulia akan membawa kebahagiaan dan manfaat bagi setiap individu. Manfaat bagi insan yang memiliki akhlak yang mulia adalah dapat memperkuat dan menyempurnakan agama, menghilangkan kesulitan, mempermudah perhitungan dunia akhirat dan selamat hidup di dunia dan akhirat.

Menurut etimologi "Akhlak" berarti budi pekerti, perangai, tingkah laku, atau tabiat (Mustofa, 1997:11). Banyak cara yang dapat dilakukan manusia dalam berakhlak kepada Allah dalam menanamkan nilai-nilai akhlak kepada Allah yang sesungguhnya akan membentuk pendidikan keagamaan. Menurut Alim (2011:153-154), Di antara nilai-nilai ketuhanan yang sangat mendasar adalah

1. Takwa, merupakan sikap untuk menyadari secara penuh di dalam hati manusia bahwa Allah selalu mengawasi segala apa yang diperbuat. Kesadaran tersebut yang dilakukan untuk selalu berusaha berbuat hanya untuk mengharap ridha dari Allah, dengan menjauhi
larangan-Nya dan menjaga diri dari sesuatu yang tidak diridhai-Nya, sehingga nilai takwa inilah yang mendasari sikap budi pekerti yang luhur atau nilai akhlakul karimah.

2. Tawakal, merupakan sikap yang selalu berusaha bersandar kepada Allah dengan penuh harapan kepada Allah. Memiliki keyakinan bahwa Allah akan menolong manusia dalam mencari dan menemukan jalan yang terbaik dalam hidupnya, karena manusia mempercayai atau menaruh kepercayaan kepada Allah, maka tawakal adalah suatu kemestian.

3. Kejujuran, yaitu mengatakan sesuatu apa adanya

4. Ikhlas, yaitu sikap murni dalam tingkah laku dan perbuatan semata-mata demi memperoleh keridhaan Allah dan bebas dari pamrih lahir dan batin.

5. Sabar, yaitu sikap tabah menghadapi segala kepahitan hidup, besar dan kecil, lahir dan batin karena keyakinan yang tak tergoyahkan bahwa kita semua berasal dari Allah dan akan kembali kepada-Nya.

6. Syukur, merupakan wujud dari sikap penuh rasa terima kasih kepada Allah dan penghargaan atas segala nikmat dan karunia yang telah diberikan dan dianugrahkan Allah kepada manusia.

Majelis Dikdasmen PP Muhammadiyah (2008:101) menyatakan organisasi Muhammadiyah merupakan suatu gerakan pemikiran Islam yang diteladani dan sekaligus sebagai gerakan dakwah juga sebuah gerakan dalam dunia pendidikan. Sejak awal berdirinya merupakan sebuah gerakan keagamaan yang sangat fokus dengan 
dunia pendidikan. Organisasi Muhammadiyah juga telah menyelenggarakan berbagai jenis lembaga dalam tingkat pendidikan yang tercakup dalam kegiatan formal, nonformal, dan informal. Dunia pendidikan Muhammadiyah mengalami kemajuan yang sangat pesat sejak berdirinya hingga saat ini. Pesatnya pendidikan Muhammadiyah dapat kita lihat dalam lembagalembaga di bawah badan amal usaha Muhammadiyah yang bergerak di bidang pendidikan (Tanfiz, 2010:37). Hal ini membuktikan bahwasannya gerakan perubahan yang dibawa oleh Muhammadiyah dengan pendidikannya menjadi sesuatu yang cukup penting dalam kehidupan berbangsa dan bernegara.

Tujuan akhlak dalam konteks pendidikan yaitu pembentukan budi pekerti yang sanggup menghasilkan orang-orang yang bermoral, jiwa yang bersih, rendah hati, sopan santun dalam berbicara dan perbuatan, percaya diri, mulia dalam tingkah laku dan perangai, tahu arti kewajiban dan pelaksanaannya, bijaksana, menghormati hak-hak manusia, tahu membedakan mana yang baik dan buruk dan senantiasa mawas diri atas posisinya sebagai kaum terpelajar. Islam sangat mengutamakan akhlak karena akhlak menjadi nomor dua setelah iman. Seseorang dikatakan orang yang beriman jika ia memiliki akhlak yang mulia (Tobroni, 2008:72).

Banyaknya persoalan yang terjadi belakangan ini antara lain disebabkan oleh semakin menipisnya nilai-nilai akhlak. Maka dari itu pemberdayaan dan penguatan nilai akhlak terhadap manusia untuk tetap teguh pendirian bukanlah menjadi perkara yang mudah untuk dilakukan. Salah satu upaya untuk menanamkan nilai-nilai akhlak tersebut adalah pemberdayaan karya sastra. Karya sastra merupakan salah satu sarana penanaman nilai-nilai kehidupan yang dapat dimanfaatkan oleh pembaca. Ajaran yang terdapat dalam novel menjadi sangat penting untuk dijadikan acuan dalam kehidupan bermasyarakat. Kehidupan bermasyrakat harus mampu membangun karakter manusia menjadi lebih baik, dapat mencerminkan karakter Islam rahmatan lil 'alamin yang menjunjung tinggi nilai akhlak, toleransi serta nilai tanggung jawab.

Karya sastra merupakan hasil cipta manusia yang bernilai estestis yang memberikan hiburan dan juga sarat dengan nilai. Masyarakat dapat mengetahui nilai-nilai, adat istiadat, keyakinan, dan pandangan hidup orang laindalam suatu kelompok masyarakat melalui karya sastra. Karya sastra hadir bertujuan untuk membicarakan mengenai persoalan manusia, karena hubungan antara karya sastra dengan manusia memiliki ikatan yang tidak terpisahkan. Permasalahan manusia dalam kehidupannya merupakan ilham atau dapat menjadikan ide bagi beberapa pengarang untuk mengungkapkan dan mengekspresikan diri dan pemikirannnya melalui karya sastra. Dengan kata lain dapat diartikan bahwa tanpa kehadiran manusia, sastra mungkin tidak ada. Sastra dikatakan memang tidak dapat dilepaskan dari manusia, baik manusia sebagai sastrawan itu sendiri, masyarakat ataupun sebagai penikmat sastra. Mencermati hal tersebut, sudah jelas bahwa manusia memang sangat berperan sebagai pendukung yang sangat menentukan dalam keberlangsungan sastra.

Penelitian dapat dilakukan dengan cara menggali karya-karya fiksi, seperti buku-buku sastra atau 
novel. Secara etimologi kata novel berasal dari bahasa latin yaitu novella. kata novella dibentuk dari kata novus yang berarti baru, dikatakan baru karena bentuk novel adalah bentuk karya sastra yang datang kemudian dari bentuk karya sastra lainnya (Santoso dan Wahyuningtyas, 2010:46). Novel merupakan karangan/karya sastra yang lebih pendek daripada roman, tetapi lebih panjang dari cerita pendek (cerpen), yang isinya mengungkapkan hanya satu kejadian yang penting atau menarik dari kehidupan seseorang.

Kathleen Kuiper (2012:1) menambahkan bahwa the novel is a genre of fiction, and fiction may be defined as the art or craft of contriving, through the written word, representations of human life that instruct or divert or both. Dalam sebuah novel, penulis novel berusaha semaksimal mungkin untuk mengarahkan pembaca kepada gambaran-gambaran realita kehidupan melalui cerita yang terkandung dalam novel tersebut. Di sisi lain, novel merupakan suatu interprestasi kehidupan dan prilaku yang nyata. Novel adalah prosa rekaan yang panjang menyuguhkan tokoh-tokoh dan menampilkan serangkaian peristiwa dan latar secara tersusun (Titian Ilmu, 2009:645). Pengertian tersebut diperkuat oleh Terry Eagleton that novel as a prose fiction of considerable length showing characters in action and capable of greater complexity in both character and plot than the sort story; moreover, according to them a novel is a book length piece of imaginative fiction (Eagleton, 1996:9).

Novel pada belakangan ini banyak yang di dalamnya terdapat pesan-pesan dakwah berisi ajaran akhlak yang baik yang seharusnya diwujudkan oleh manusia. Akhlak mulia adalah hal yang terpenting yang harus dimiliki dan dijadikan pedoman hidup dalam berprilaku manusia. Salah satu novel yang menampilkan nilainilai akhlak yaitu novel Guru Aini karya Andrea Hirata.

Novel Guru Aini berisi tentang perjalan seorang pemuda yang bercitacita menjadi seorang guru matematika. Pemuda tersebut sangat idealis dan gigih dalam memperjuangkan keinginannya sehingga pemuda tersebut berada dalam keluarga menengah ke atas. Begitu pula ketika pemuda tersebut sudah mencapai keinginannya untuk menjadi guru. Profesi guru yang dihadapi oleh pemuda tersebut tidaklah mudah, banyak halangan dan rintangan dalam menghadapi pembelajaran matematika yang hampir seluruh siswa menolak tetapi pemuda ini menunjukkan kegigihannya lagi dengan cara terus memotivasi siswa bahwa belajar matematika itu mudah.

Novel karya Andrea Hirata tinggi akan nilai-nilai akhlak yang menceritakan realitas sosial, gambaran yang sesungguhnya terjadi dalam kehidupan masyarakat. Cerita pada novel Guru Aini juga menampilkan nilai tentang perjuangan, kesabaran, sikap perduli terhadap sesama manusia. Secara tidak langsung cerita pada novel memberikan pengaruh terhadap kehidupan bermasyarakat. Dengan demikian, cerita dalam novel Guru Aini ini dapat dijadikan sebagai media dalam menyampaikan pesan terhadap masyarakat tentang pentingnya perilaku terhadap sesama. Menurut Yenhariza (2012:168), novel sebagai alat untuk mendidik agar mengerti dan memahami berbagai persoalan kehidupan yang dialami manusia. Dengan membaca novel, pembaca akan mengetahui mana perilaku baik yang 
harus ditiru dan perilaku yang harus ditinggal.

Novel Guru Aini menarik untuk diteliti bahwa dalam cerita tersebut menyampaikan nilai-nilai akhlak yang sangat kental dalam kehidupan bermasyarakat. Nilai akhlak dapat dijadikan sebagai pengembangan akhlak terhadap masyarakat untuk mengembangkan pribadi masyarakat menjadi individu yang lebih baik menurut agama dan kehidupan bermasyarakat. Nilai yang terdapat dalam novel Guru Aini seharusnya dimiliki oleh umat manusia, hal ini menjadi cukup menarik untuk diteliti dengan menggunakan analisis sosiologi sastra. Menurut Endraswara (2003:79), sosiologi sastra adalah penelitian yang terfokus pada masalah-masalah manusia karena karya sastra mengungkapkan perjuangan manusia dalam menuntukan masa depan berdasarkan imajinasi, perasaan, dan intuisi. Hal lainnya menyebutkan bahwa pendekatan sosiologi melihat konfrontasi dan pertikaian yang berlaku dalam masyarakat sebagai sumber inspirasi penulis.

\section{METODE}

Metode penelitian yang digunakan adalah metode kualitatif dan pendekatan analisis isi. Emzir (2011:284) menjelaskan metode kualitatif adalah analisis yang dapat melibatkan suatu jenis analisis, di mana isi komunikasi (percakapan, teks tertulis, wawancara, fotografi dan sebagainya) dikategorikan dan diklasifikasikan. Menurut Bogdan dan Taylor dalam Moleong (2007:4), metode penelitian kualitatif adalah prosedur penelitian yang menghasilkan data deskriptif berupa kata-kata tertulis atau lisan dari orang-orang dan perilaku yang dapat diamati. Dalam hal ini penelitian kualitaitif menghasilkan prosedur analisis yang tidak menggunakan analisis statistik atau cara kuantifikasi lainnya.

Data dalam penelitian ini adalah mengenai nilai-nilai akhlak dalam bentuk kalimat, klausa, dalam bentuk tertulis. Sumber data adalah subjek penelitian dari mana data diperoleh (Siswantoro, 2010:63). Ada dua jenis data: data primer dan sekunder. Data primer adalah data utama yang diproses langsung dari sumbernya novel Guru Aini tanpa melalui perantara. Sedangkan data sekunder adalah data yang berfungsi untuk memperkaya, mempertajam analisis yang diambil dari jurnal, majalah dan buku-buku kritik sastra. Data primer dalam penelitian ini berupa novel yang berjudul Guru Aini karya Andrea Hirarta, sedangkan sumber data sekunder berupa buku nilai-nilai ahklak dan buku-buku kritik sastra yang mendukung penelitian data primer, serta review yang berhubungan dengan data primer.

Prosedur pengumpulan data dalam kegiatan penelitian ini terdiri dari dua unsur, yaitu: (1) teknik pengumpulan data dan (2) instrumen pengumpulan data. Dokumen bisa berbentuk tulisan, gambar, atau karyakarya monumental dari seseorang. (Sugiyono, 2007:240)

Teknik pengumpulan data dalam penelitian ini dilakukan dengan beberapa cara, yaitu:

a. Membaca sekaligus memahami isi cerita yang ada di dalam novel Guru Aini secara mendalam untuk menemukan data yang menunjukan keberadaan masalah.

b. Melakukan klasifikasi dengan menggolongkan dengan nilai- 
nilai akhlak yang terdapat dalam novel Guru Aini.

c. Melakukan studi kepustakaan untuk mendapatkan data tambahan sebagai data penunjang dan pelengkap mengenai nilai-nilai akhlak.

Selanjutnya, penelitian ini menggunakan instrumen penelitian yang merupakan peneliti sendiri yang dibantu oleh tabel-tabel analisis kerja berdasarkan subfokus penelitian nilainilai akhlak dalam novel Guru Aini. Tabel yang digunakan oleh peneliti yaitu untuk mengelompokkan nilainilai akhlak yang dianalisis. Tabel tersebut digambarkan seperti berikut:

Tabel 1 Bentuk Nilai-Nilai Akhlak

\begin{tabular}{|c|l|c|c|}
\hline No & \multicolumn{1}{|c|}{ Indikator } & Kutipan & Hlm \\
\hline 1 & Takwa & & \\
\hline 2 & Tawakal & & \\
\hline 3 & Kejujuran & & \\
\hline 4 & Keikhlasan & & \\
\hline 5 & Sabar & & \\
\hline 6 & Syukur & & \\
\hline
\end{tabular}

Tabel 2 Kriteria Bentuk Nilai-Nilai Akhlak

\begin{tabular}{|l|l|l|}
\hline No & Bentuk Nilai & \multicolumn{1}{c|}{ Kriteria } \\
\hline $\mathbf{1}$ & Takwa & $\begin{array}{l}\text { Takwa, merupakan suatu bentuk sikap yang menyadari secara } \\
\text { penuh bahwa Allah selalu mengawasi kehidupan manusia, sehingga } \\
\text { manusia selalu berusaha untuk berbuat sesuatu hanya mengharap } \\
\text { ridha dari Allah, dan berusaha untuk menjauhi segala larangan } \\
\text { Allah serta sellau berusaha untuk menjaga diri dari sesuatu yang } \\
\text { tidak baik. Takwa inilah yang mendasari nilai budi pekerti yang } \\
\text { luhur atau akhlakul karimah untuk manusia. }\end{array}$ \\
\hline $\mathbf{2}$ & Tawakal & $\begin{array}{l}\text { Merupakan sikap pada diri manusia yang senantiasa berusaha untuk } \\
\text { bersandar kepada kehendak Allah. Memiliki keyakinan bahwa } \\
\text { Allah akan menolong manusia ketika dalam kesulitan. Ketika } \\
\text { manusia percaya akan takdir Allah, maka tawakal sudah menjd } \\
\text { ebuah keniscayaan. }\end{array}$ \\
\hline $\mathbf{3}$ & Kejujuran & $\begin{array}{l}\text { Merupan sikap yang selalu berkata apa adanya, tidak dibuat-buat, } \\
\text { berusaha untuk selalu berkata yang benar. }\end{array}$ \\
\hline $\mathbf{5}$ & Keikhlasan & $\begin{array}{l}\text { Merupakan sikap yang senantiasa berserah pada Allah dan hanya } \\
\text { mengharap ridha dari Allah saja. Tidak memiliki sifat pamrih, } \\
\text { mengharap balasan dari sesama manusia. }\end{array}$ \\
\hline $\mathbf{6}$ & Syukur & $\begin{array}{l}\text { Merupakan sikap tabah dalam menghadapi ujian dari Allah, } \\
\text { menerima kepahitan hidup baik besar atau kecil, ikhlas secara lahir } \\
\text { dan batin. Manusia memiliki keyakinan bahwa dia akan kembali } \\
\text { pada Allah }\end{array}$ \\
\hline $\begin{array}{l}\text { Merupakan sikap penuh rasa terima kasih pada Allah, selalu } \\
\text { berucap ukur merupakan suatu wujud penghargaan yang tinggi } \\
\text { pada Allah atas nikmat yang sudah diberikan. }\end{array}$ \\
\hline
\end{tabular}

Data yang telah ditemukan dalam penelitian ini dideskripsikan dan dikelompokan menurut Nurgiyantoro yang menyatakan bahwa analisis unsur stile dilakukan dengan mengidentifikasi masing-masing unsur 
dengan tanpa mengabaikan konteks, menghitung frekuensi kemunculannya, menafsirkan dan mendeskripsikan kontribusinya bagi stile karya fiksi secara keseluruhan (Nurgiyantoro: 2007:23).

\section{HASIL DAN PEMBAHASAN Sinopsis Novel}

Tekad yang bulat, jiwa yang kuat, dan keteguhan hati yang mantap bisa dibuktikan oleh remaja yang bernama Desi dari Sumatra Barat. Sejak kecil Desi penggagum guru matematika yang bernama $\mathrm{Bu}$ Marlis. Mulai dari situlah Desi bercita-cita menjadi guru matematika, padahal teman-teman Desi hampir seluruhnya tidak menyukai mata pelajaran Matematika. setelah Desi menyelesaikan jenjang SMA, Desi langsung mengikuti program pemerintah D3 Jurusan Matematika yang nantinya setelah menyelesaikan program tersebut langsung menjadi guru matematika yang akan dikirim keseluruh wilayah Indonesia yang masih kekurangan guru matematika. Sebelum Desi mengikuti program tersebut, orang tua Desi membujuk untuk tidak mengkuti program tesebut karena orang tua Desi tidak mau melihat anaknya tinggal di pelosok-pelosok yang jauh dari peradaban, bahkan orang tua Desi meminta seorang guru untuk membatalkan masuk pada program tersebut. Tetapi dengan keteguhan hati Desi, tidak ada satu orang pun yang bisa membujuk Desi agar tidak mengikuti program tersebut, padahal Desi adalah anak yang cantik dan pintar. Bisa saja Desi masuk perguruan tinggi negeri yang berkualitas dan masuk ke jurusan kedokteran. tetapi entah kenapa Desi sangat keras hati untuk menjadi guru matematika yang sudah lama menjadi cita-cita Desi.

\section{Temuan Penelitian Nilai Takwa}

Takwa berarti percaya bahwa Allah selalu mengawasi makhluknya, dan menjadikan makhluknya melakukan apa yang diridhai oleh-Nya. Takwa sebagaimana yang sudah dijelaskan sebelumnya sejalan dengan novel Guru Aini karya Andrea Hirata. Hal ini dapat dibuktikan dengan kutipan pada novel tersebut, yaitu:

"Tak berminat menjadi model, Bu. Negeri ini kekurangan guru matematika, Bu, terutama di kampung-kampung. Pemerintah sedang menyiapkan generasi untuk membangun teknologi karena itu pemerintah bikin program D-3 untuk mencetak guru-guru matematika ini. Ini program yang sangat bagus, Bu, kita harus dukung. "(Halaman 2)

Pada kutipan tersebut digambarkan bahwa sosok Desi sudah memantapkan hatinya untuk menjadi guru, walaupun sudah diiming-imingi pekerjaan lain jika mengambil jurusan kuliah bukan pendidikan. Tetapi, Desi tetap pada pendiriannya. Ia percaya bahwa jika ia menjadi seorang guru, kelak akan membantu pemerintah dalam memajukan negara dengan cara mencerdaskan generasi muda yang tentunya membuat perubahan.

Desi, merasa tidak enak hati telah menolak dengan keras saran yang diberikan guru dan ibunya. Mereka membujuknya untuk berkuliah dengan jurusan lain agar nantinya ia dapat bekerja di kota dan bisa kedepannya akan dapat hidup mudah. Apalagi Desi adalah seorang yang cerdas, tentu akan sangat mudah mendapatkan pekerjaan yang bagus di kota. Namun, apalah daya, Desi tetap mempertahankan 
pilihannya. Hal ini diperkuat melalui kutipan berikut.

"Sempat dia merasa tak enak hari karena begitu keras mempertahankan pendapatnya. Namun apa boleh buat, dia ingin jujur pada dirinya sendiri, bahwa yang paling diinginkannya adalah menjadi guru matematika yang mengajar anak-anak miskin dipelosok" (Halaman 3)

\section{Nilai Tawakal}

Tawakal berarti sikap selalu bersandar kepada Allah dengan penuh harapan kepada-Nya dan keyakinan bahwa Dia akan menolong manusia dalam mencari dan menemukan jalan yang terbaik. Masalah tawakal ini dapat dilihat dari Novel Guru Aini sebagaimana pada kutipan berikut.

"Dalam pemikiran Guru Desi, jika dia berhasil menemukan dan mendidik seorang anak Kampung Ketumbi menjadi genius matematika, maka anak-anak Kampung Ketumbi lainnya akan melihat bahwa mereka pun bisa meraih sesuatu yang selalu mereka bayangkan tak mungkin dapat mereka raih." (Halaman 50)

Pada kutipan di atas, guru Desi sangat yakin bahwa ia dapat menemukan seorang anak yang sangat genius, dan nantinya dapat menjadikannya sebagai panutan bagi warga setempat. Walaupun mencari anak genius yang memenuhi kriterianya sangatlah sulit, tetapi ia percaya bahwa suatu saat akan muncul anak genius yang akan dididik olehnya. Bahkan saking yakinnya akan hal itu, ia semacam bersumpah pada dirinya sendiri dan ia rela dinilai aneh oleh masyarakat, hal itu dapat dilihat pada kutipan berikut

"Desi berjanji pada dirinya
sendiri, dia mengangkat
semacam sumpah sepatu,
bahwa dia akan terus memakai
sepatu olahraga pemberian
ayahnya, sampai anak genius
matematika ditemukannya."
(Halaman 50)

Pada awal mengajar, saat semangatnya sedang membara, Guru Desi menemukan murid genius matematika pertamanya, Debut namanya. Guru Desi sangat bangga dan sangat mengelu-elukan Debut, tapi sayang suatu hari Debut mulai berhenti belajar, bahkan pindah tempat duduk menjadi barisan paling belakang dan tidak lama Debut memutuskan untuk berhenti sekolah. Guru Desi sangat terpukul, harapannya pupus, dunianya seakan runtuh. Bagaimana tidak seorang genius matematika yang ia cari selama ini pergi begitu saja. Walaupun kepergian Debut membuat Guru Desi berubah derastis menjadi guru yang galak dan disegani, Guru Desi tetap berusaha menemukan pengganti debut. Ia sangat gigih dan tidak mudah putus asa. Hal ini dapat dibuktikan pada kutipan novel berikut.

"Dia berusaha introspektif dan
kreatif. Kerap didesainnya
kurikulum matematikanya
sendiri, dicobakannya pada
murid-murid, dan gagal juga."
(Halaman 68)

Pada novel ini, diceritakan bahwa Aini sangat tidak tertarik pada matematika, bahkan dapat dibilang sangat tidak menyukai matematika 
sehingga nilai matematika pada setiap ulangan hanya kisaran 0 sampai 1 . Namun, Aini tiba-tiba memiliki tekad yang kuat untuk menguasai matematika, demi menjadi seorang dokter agar bisa menyembuhkan ayahnya yang sakit. Ia rela belajar dengan guru yang sangat ditakuti dan disegani di sekolahnya, Guru Desi. Hal ini dapat dilihat dari kutipan berikut.

"Dia hanya ingin berada di kelas Guru Desi. Maka Aini berpikir keras mencari cara melepaskan diri dari kutukan bilangan biner. dan Dia bertekad tak mau lagi dapat nilai ulangan matematika 0 atau 1. Pada ulangan minggu depan dia akan meningkatkan target nilainga secara signifikan, yaitu menjadi 2." (Halaman 141)

Walaupun menjadi genius matematika tidaklah mudah, Aini tetap pada pendiriannya. Di dalam hati dan pikirannya hanya memikirkan bagaimana caranya ia harus menjadi dokter, demi ayahnya. Oleh karena itu ia tidak akan menyerah pada pelajaran yang menurutnya sangat sulit itu. Hal ini dapat dilihat pada kutipan berikut.

"Tak peduli panas, mendung, hujan, banjir, guruh, petir, dia pasti ke rumah Guru Desi untuk belajar matematika, dan pasti kena damprat." (halaman 169)

\section{Nilai Kejujuran}

Kejujuran yaitu mengatakan sesuatu apa adanya yang sesuai dengan isi hati dan pikiran. Sebelum mendaftarkan dirinya untuk kuliah dengan jurusan pendidikan, Desi ditanya oleh ibu dan gurunya. Alasan mengapa ia sangat ingin menjadi guru matematika. Rupanya, hal tersebut dimotivasi oleh guru SD Desi, ia sangat mengidolakan gurunya tersebut. Menurut Desi, gurunya tersebut bagaikan pahlawan bagi muridmuridnya. Dengan kemampuan mengajar yang sangat menakjubkan, Desi bertekad mulai saat itu untuk mengikuti jejak gurunya itu. Hal ini diutarakan Desi dalam kutipan berikut.

"Karena... karena matematika adalah salah satu ilmu yang paling banyak memecahkan misteri, karena matematika dapat mengubah peradaban, karena ingin menjadi seperti Ibu Marlis." (Halaman 18)

Setelah menjadi guru, Desi mendapat banyak sekali pengalaman mengajar dan tidak ada satupun yang dengan suka rela belajar dengannya karena gaya yang dimilikinya. Tetapi, suatu hari ada murid yang datang kepadanya untuk belajar matematika langsung dengannya, murid itu adalah Aini. Karena merasa tertarik sekaligus penasaran terhadap Aini, akhirnya Desi menanyakan alasan Aini untuk belajar dengannya. Desi sangat terkejut mendengar jawaban Aini.

"Aku mau pintar matematika karena ayahku sakit, Bu, sakit keras, tak ada obatnya. Sudah hampir setahun tergeletak saja di tempat tidur. Aku ingin pintar matematika agar dapat masuk fakultas kedokteran, Bu. Aku ingin menjadi dokter ahli, agar bisa mengobati ayahku." (Halaman 99)

Ketika Aini ditanya oleh Guru Desi, mengapa ia memilih untuk belajar 
dengan Guru Desi yang sangat garang, berikut adalah jawaban jujur Aini pada kutipan novel tersebut.

"Dapat belajar matematika dari Ibu adalah kesempatan terbaik yang pernah kudapat dalam hidupku, Bu. Aku tak ingin belajar matematika pada orang lain." (Halaman 142)

Sejalan dengan hal itu, Aini berkata bahwa selama ini, ia sudah muak menjadi murid yang tidak tahu apa-apa. Meskipun ia sudah memasuki jenjang sekolah menengah atas, hal ini dapat dibuktikan pada kutipan berikut.

"Sudah terlalu lama aku menjadi anak bodoh, Bu. Aku trauma menjadi anak bodoh. Aku tak mau kembali menjadi anak bodoh." (Halaman 247)

\section{Nilai Keikhlasan}

Ikhlas merupakan sikap menerima dalam tingkah laku dan sikap serta perbuatan yang semata-mata hanya demi memperoleh keridhaan Allah dan bebas dari pamrih lahir dan batin dari manusia. Seperti halnya dalam novel ini diceritakan bahwa Guru Desi ikhlas mengajar matematika, hingga ia menolak hampir semua pemberian wali murid sebagai ucapan terima kasih karena sudah mau mengajar anak mereka, dan bantuan dari orang tuanya. Hal ini dapat dibuktikan pada kutipan berikut.

"Karena itu Guru Desi tak punya harta. Dia pun selalu menolak bantuan uang dari ibunya yanng kaya karena katanya dia telah mandiri." (halaman 135)
Selain itu, novel ini memberikan amanat pada pembaca agar ikhlas dalam menjalankan sesuatu dan menikmati setiap proses yang terjadi dalam hidup. Hal ini dapat dibuktikan pada kutipan berikut.

"Dalam perjalanan yang panjang menuju keikhlasan, kita akan menemukan harapan. Dalam perjalanan yang berliku-liku menuju pengorbanan, kita akan menemukan keberanian. Namun kejujuran pada diri sendiri, akhirnnya kita pulang". (Halaman 216)

Akhir cerita, Aini diceritakan berhasil masuk fakultas kedokteran seperti yang ia inginkan. Dengan segala upaya ia lakukan, demi masuk dan berkuliah di fakultas kedokteran. Namun, apa daya biaya kuliah yang begitu mahal membuatnya harus mengikhlaskan keinginannya itu. Merelakan mimpi terbesarnya, walaupun tidak mudah untuk berlapang dada menerima hasil akhirnya dan segala usaha yang dilakukannya selama ini terasa sia-sia. Aini tetap tegar menghadapi kenyataan, hal ini dapat dibuktikan pada kutipan berikut.

"Dia tahu dia telah berhasil masuk fakultas kedoktean namun dia juga tahu dia telah gagal masuk fakultas kedokteran". (Halaman 284)

\section{Nilai Kesabaran}

Dalam novel Guru Aini, diceritakan tokoh Aini sangat anti dengan matematika, hingga akhirnya ketika Ayahnya sakit, ia berubah secara derastis. Memiliki ambisi menjadi genius matematika menjadinya dicibir 
orang sekitarnya, karena orang disekitarnya paham betul bagaimana Aini, mereka sudah merasa sangat pesimis pada Aini. Jangankan menjadi genius matematika, mendapatkan nilai 5 dalam ulangan rasanya tidak mungkin. Apalagi ketika Aini memutuskan untuk pindah kelas dan belajar matematika dari guru yang sangat ditakuti, yang sangat tegas akan sistem belajar di kelasnya. Walaupun Aini mendapat cibiran, ledekan, yang membuatnya semakin tertekan tetapi ia tidak memedulikan hal itu, jelaslah hal ini membuktikan sikap sabar Aini. Hal tersebut dapat dilihat pada kutipan berikut.

"Aini telan pahit-pahit ledekan yang makin sering didengarnya dari kawan-kawan sekelas barunya itu." (Halaman 136)

\section{Nilai Syukur}

Syukur yaitu sikap penuh terima kasih dan penghargaan atas segala nikmat dan karunia yang tidak terbilang banyaknya yang dianugrahkan Allah kepada manusia. Hal ini sejalan dengan penokohan dalam novel Guru Aini karya Andrea Hirata yang dapat dibuktikan pada kutipan berikut,

"Dia hidup sendiri di rumah dinas tipe 21 di perumahan guru, tak ada furnitur, apalagi sofa. Tak ada benda elektronk maupun hiasan. Yang ada hanya buku yang bertumpuktumpuk di sudut-sudut". (Halaman 135)

Tentunya hal ini merupakan sikap Guru Desi, walaupun pada kenyataannya ia memiliki hidup yang berkecukupan, dan juga bisa saja ia hidup makmur di desa tersebut berkat bantuan juga hadiah dari setiap wali murid anak muridnya, ia merasa hidup seperti itu sudah cukup.

Seiring berjalannya waktu, Aini yang tadinya merasa dirinya gelap akan angka mengalami peningkatan, setelah ditemukannya metode belajar yang cocok untuknya oleh Guru Desi. Setiap sore Guru Desi tak henti-hentinya memberikan Aini makanan berupa angka-angka tersebut. Dan Guru Desi merasa usahanya tidak sia-sia setiap sore memberi makan Aini angka itu, hal ini dapat dibuktikan pada kutipan berikut.

"Tersenyum bangga Guru Desi
membuka buku ulangannya dan
memperlihatkan nilainya yang
mulai menyundul-nyundul
angka 7 dan 8." (Halaman 218)

Berkat kerja keras Guru Desi dan semangat Aini dalam belajar, Aini merasa pencapaiannya sudah mulai terlihat hasilnya ia sangat bersyukur dapat dididik oleh Guru Desi, hal ini dubuktikan melalui kutipan berikut.

\section{"Kekagumanku padamu adalah sumur tak berdasar, Guru. Sungguh luas pengetahuanmu. Betapa beruntungnya aku menjadi muridmu." (Halaman 240)}

Setelah perjalanan panjang yang ditempuh oleh Aini dan Guru Desi, sampailah mereka ditujuan akhir, yaitu kelulusan sekolah. Aini berhasil lulus menjadi salah satu murid terbaik di sekolahnya. Tentu saja ini berkat semangat dan kemauannya yang tinggi dalam berusaha menjadi genius matematika, dan dukungan orang tua serta Guru Desi. Ibu Aini, yang dulu 
juga merupakan murid Guru Desi tak percaya anaknya itu berhasil dididik Guru Desi. Ibu Aini merasa tidak menyangka anaknya yang dianggap fobia terhadap angka akhirnya bisa menjadi salah satu lulusan terbaik sekolah tersebut. Hal ini dibuktikan dengan kutipan berikut.

"Ibu Aini berdiri terharu di pojok sana. Dia seakan tak percaya akan apa yang baru dikatakan Kepala Sekolah. Berkaca-kaca matanya." (Halaman 269)

Guru Desi juga sangat bersyukur memiliki murid seperti Aini yang tidak mudah menyerah, dan sabar terhadapnya. Berkat Aini juga Guru Desi dapat mewujudkan cita-citanya untuk mendidik seorang genius matematika. Hal ini dapat dibuktikan dengan kutipan berikut.

"Oh, terbalik, Aini, kaulah yang telah memperlihatkan dunia padaku. Sebelumnya kusangka di dunia ini tak ada murid sepertimu. Bertahun-tahun mengajar, tak pernah aku melihat muid begitu gigih belajar sepertimu. Lihatlah sekarang, dalam tingkatanmu, kau telah menguasai matematika, salah satu ilmu paling sulit di dunia ini. Kau adalah perempuan muda Indonesia yang hebat, Aini." (Halaman 271)

\section{PENUTUP}

\section{Simpulan}

Berdasarkan seluruh uraian dan pembahasan tentang nilai-nilai Akhlak yang terkandung dalam novel Guru Aini karya Andrea Hirata, selanjutnya dapat diambil kesimpulan bahwa novel
Guru Aini karya Andrea Hirata sarat akan nilai-nilai Akhlak yang dapat dijadikan sebagai contoh yang baik untuk pembaca novel ini. Novel ini disajikan dalam gaya bahasa yang cukup mudah dimengerti serta tokoh utamanya sangat inspiratif untuk dijadikan tauladan bagi kaum muda yang sedang meraih cita-cita. Di dalam novel ini terdapat 6 kutipan dari nilai takwa, 14 kutipan nilai tawakal, 18 kutipan dari nilai kejujuran, 4 kutipan dari nilai keikhlasan, 1 kutipan dari nilai sabar, dan 14 kutipan dari nilai syukur. Melalui novel tersebut, pembaca dapat mengambil banyak manfaat dan pembelajaran yang ada di dalam cerita, karena novel tersebut disajikan melalui perpaduan kisah nyata yang dialami oleh penulis dengan kisah sehari-hari yang diimajinasikan oleh penulis.

\section{Saran}

Nilai-nilai Akhlak dalam novel Guru Aini karya Andera Hirata dapat diaplikasikan dalam kehidupan seharihari, baik dalam kegiatan belajar mengajar di sekolah maupun dalam pergaulan di lingkungan masyarakat.

Kajian tentang nilai-nilai Akhlak dalam novel Guru Aini karya Andrea Hirata ini belum dikatakan sempurna, karena keterbatasan waktu, pengetahuan, metode, dan ketajaman analisis yang peneliti miliki. Untuk itu, tidak menutup kemungkinan penelitipeneliti yang lain akan berkenan mengkaji ulang novel Guru Aini karya Andrea Hirata.

\section{UCAPAN TERIMA KASIH}

Terima kasih kepada Rektor Universitas Muhammadiyah Jakarta, LPPM Universitas Muhammadiyah Jakarta atas pendanaan dan fasilitasnya kepada Dekan Fakultas Ilmu 
Pendidikan serta Ketua Program Studi Pendidikan Bahasa dan Sastra Indonesia atas motivasinya kepada penulis sehingga penelitian ini terlaksana dengan baik.

\section{DAFTAR PUSTAKA}

Atjeh, Abu Bakar. (2007). Filsafat dalam Islam. Semarang: CV. Ramadhani

Alim, Muhammad. (2011). Pendidikan Agama Islam: Upaya Membentuk Kepribadian Muslim. Bandung: PT Remaja Rosdakarya.

A, Mustofa. (1997). Akhlak Tasawuf. Bandung: Pustaka Setia.

Emzir. (2011). Metodologi Penelitian Kualitatif. Jakarta: Raja Grafindo Persada.

Endraswara, Suwardi. Metodologi Penelitian Sastra. (2003). Yogyakarta: Pustaka Widyatama.

Eagleton, Terry. (1996). Literary Theory UK: Blackwell Publishing.

Hirata, Andrea. (2020). Guru Aini. Yogyakarta: Bentang Pustaka

Ilmu, Titian. (2009). Ensiklopedia Sastra Indonesia. Bandung: Titian Ilmu

Kuiper, Kathleen. (2012). Prose: Literary Terms and Concept. New York: Britannica Educational Publishing.
Majelis Dikdasmen PP Muhammmadiyah. (2008). $A L$ Islam dan Kemuhammadiyahan Kelas X Semester I. Yogyakarta: Mentari Pustaka.

Moleong, Lexy. J. (2007) Metodologi Penelitian Kualitatif Bandung: PT Remaja Rosda Karya.

Nurgiyantoro, Burhan. (2007). Teori Pengkajian Fiksi. Yogyakarta: Gadjah Mada Press.

Santoso, Wijaya Heru dan Sri Wahyuningtyas. (2010). Pengantar Apresiasi Prosa. Surakarta: Yuma Pustaka.

Siswantoro. (2010). Metode Penelitian Sastra Analisis Psikologi. Surakarta: Yuma Pustaka.

Sugiyono. (2007). Metode Penelitian Kuantitatif, Kualitatif dan $R \& D$. Bandung: Alfabeta.

Tanfiz: (2010). Keputusan Muktamar Satu Abad Muhammadiyah. Yogyakarta: Pimpinan Pusat Muhammadiyah.

Tobroni. (2008). Pendidikan Islam Paradigma Teologis, Filosofis dan Spiritualis. Malang: UMM Press.

Yenhariza, (2012). "Nilai-nilai Pendidikan dalam Novel Eliana Karya Tere Liye" Jurnal Pendidikan Bahasa dan Sastra Indonesia. Vol. 1. No. 1. 